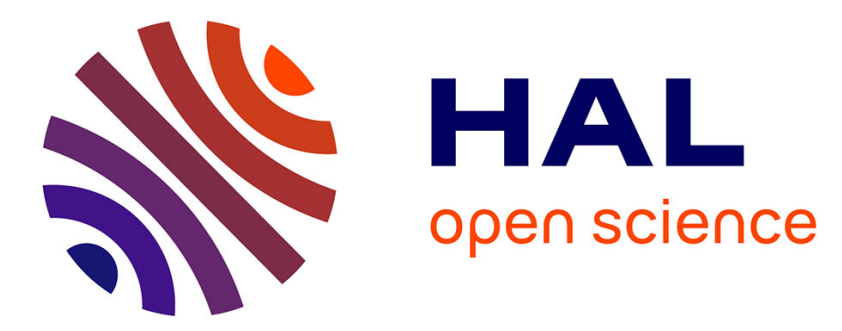

\title{
Medical image illumination enhancement and sharpening by using stationary wavelet transform
}

Pejman Rasti, Morteza Daneshmand, Fatih Alisinanoglu, Cagri Ozcinar, Gholamreza Anbarjafari

\section{To cite this version:}

Pejman Rasti, Morteza Daneshmand, Fatih Alisinanoglu, Cagri Ozcinar, Gholamreza Anbarjafari. Medical image illumination enhancement and sharpening by using stationary wavelet transform. 2016 24th Signal Processing and Communication Application Conference (SIU), May 2016, Zonguldak, Turkey. pp.153-156, 10.1109/SIU.2016.7495700 . hal-02528732

\section{HAL Id: hal-02528732 \\ https://univ-angers.hal.science/hal-02528732}

Submitted on 2 Sep 2021

HAL is a multi-disciplinary open access archive for the deposit and dissemination of scientific research documents, whether they are published or not. The documents may come from teaching and research institutions in France or abroad, or from public or private research centers.
L'archive ouverte pluridisciplinaire HAL, est destinée au dépôt et à la diffusion de documents scientifiques de niveau recherche, publiés ou non, émanant des établissements d'enseignement et de recherche français ou étrangers, des laboratoires publics ou privés. 


\title{
Kalıcı Dalgacık Dönüşümü Kullanarak Tıbbi İmge Aydınlatma Pekiştirme ve Netleşme Medical Image Illumination Enhancement and Sharpening by Using Stationary Wavelet Transform
}

\author{
Pejman Rasti ${ }^{1}$, Morteza Daneshmand ${ }^{1}$, Fatih Alisinanoglu ${ }^{2}$, Cagri Ozcinar ${ }^{3}$, and Gholamreza Anbarjafari ${ }^{1,2}$ \\ ${ }^{1} \mathrm{iCV}$ Research Group, Institute of Technology, University of Tartu, Tartu, Estonia \\ \{pejman.rasti,mortezad,shb\}@ut.ee \\ ${ }^{2}$ Dept. of Electrical and Electronic Eng., Hasan Kalyoncu University, Gaziantep, Turkey \\ fatih.alisinanoglu@hku.edu.tr \\ ${ }^{3}$ Institut Mines-Télécom, Télécom ParisTech, Paris, France \\ cagri.ozcinar@telecom-paristech.fr
}

\begin{abstract}
Özetçe -Çeşitli cihazlarla elde edilebilen tıbbi imgelerdeki ışıklandırma, hastanın tedavisinde kullanılan kimyasallardan dolayı farklılıklar gösterebilmektedir. Örneğin düşük kontrast veya çok parlak bir MRI imgesinin analizi düşü̈k bilgi içeriği nedeniyle uzmanlar tarafindan daha zor yapılacaktır. Bahsedilen bu probleme çözüm olabilmesi için bu makalede durağan dalgacık dönüşümü tabanlı yeni bir imge pekiştirme metodu önerilmektedir. Önerilen metod imge ışıklandırmasını pekiştirecek ve daha seçik imge elde edecektir. Önerilen metod, girdi imgesini durağan dalgacık dönüşümü kullanarak dört alt bölgeye ayırmaktadır. Ayrılan bölgelerdeki düşük-düşük alt bölge imgesinin ışıklandırması pekiştirilmektedir. Daha sonra yüksek frekanslı alt bölge imgesi girdi imgesine eklenerek ayrıt pekiştirilmesi yapılmaktadır. Bu metod, literatürde en gelişkin kontrast pekiştirme metodları olarak bilinen histogram eşitleme, yerel histogram eşitleme, tekil değer eşitleme, tekil değer ayrık dalgacık dönüşümü takiben tekil değer ayrıştırma metodlarıyla karşılaştırılmıştır. Deneysel sonuçlar önerilen metodun diğer en gelişkin metodlara göre daha üstün olduğunu doğrulamaktadır.
\end{abstract}

Anahtar Kelimeler-Tıbbi imge netleşme, kalıcı dalgacık dönüşümü, tıbbi imge işleme, tıbbi imge pekiştirme

Abstract-Medical images captured by various devices have different illumination states based on chemicals used by patient prior to scanning. Consider a MRI image which has low contrast or is too bright, hence the experts cannot analysis that image due to poor representation of data in the image. In this paper we are proposing new medical image illumination enhancement and sharpening technique based on stationary wavelet transform which is addressing the aforementioned problem. The technique decomposes the input medical image into the four frequency subbands by using stationary wavelet transformation and enhances the illumination of the low-low subband image, and then it enhanced edges of image by adding the high frequency subbands to the image. The technique is compared with the conventional and state-of-art image illumination enhancement techniques such as histogram equalisation, local histogram equalisation, singular value equalisation, and discrete wavelet transform followed by singular value decomposition contrast enhancement techniques. The experimental results are showing the superiority of the proposed method over the conventional and the state-of-art techniques.
Keywords-medical image sharpening, stationary wavelet transformation, medical image processing, medical image enhancement

\section{INTRODUCTION}

Contrast enhancement is frequently referred as one of the most important issues in image processing. Contrast is created by the difference in luminance reflected from two adjacent surfaces. In other words, contrast is the difference in visual properties that makes an object distinguishable from other objects and the background. If the contrast of an image is highly concentrated on a specific range, e.g. a dark image, the information may be lost in those areas which are excessively and uniformly concentrated. The problem is to optimize the contrast of an image in order to represent all the information in the input image.

Nowadays medical image processing is playing an important role in our life, such as brain MRI, Mammography, and surgeries. Contrast of a medical image is one of the most important quality factors [1]. The difference in the color and brightness of the object with other objects determines the contrast [2], [3]. Furthermore, the sharpness of the images plays an important role in studying of the obtained images [4]. If an image is highly illuminated or if it is blurred, the information may be lost or difficult to extract. The main issue is to enhance the illumination and sharpness of an image without loss of information. Various techniques exits in order to overcome this issue [5]-[9], such as General Histogram Equalization (GHE) and Local Histogram Equalization (LHE) for illumination enhancement and applying Laplacian transform in order to sharpen the image. In this work, we are comparing our results with two state-of-art techniques, namely, Brightness Preserving Dynamic Histogram Equalization (BPDHE) [10], [11] and Discrete Wavelet Transformation (DWT) and Singular Value Decomposition (SVD) based illumination enhancement [2], [12].

GHE technique is one of the simplest and most trivial techniques for contrast enhancement in many image processing applications [13], [14]. BPDHE is obtained from Dynamic His- 


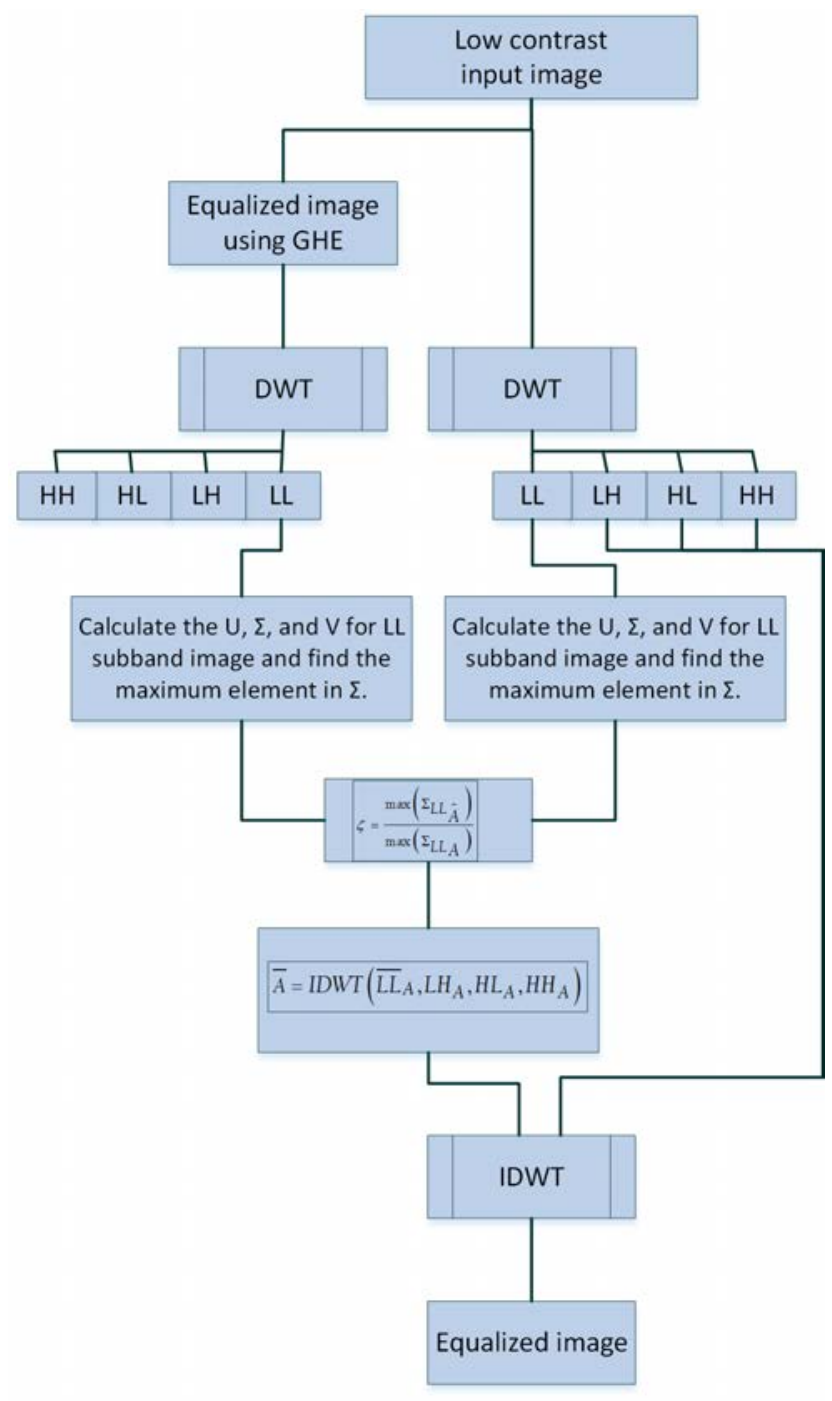

Şekil 1: The detailed steps of the DWT and SVD based equalization technique [2].

togram Specification (DHS) [15] which generates the specified histogram dynamically from the input image.

As Demirel et al. proposed in [2], DWT and SVD based image illumination enhancement technique is based on updating the singular value matrix obtained by SVD in low-low subband of input image obtained by applying DWT. Fig. 1 is showing the general algorithm of this method [2]. The main idea of using SVD in [2] for image equalization comes from this fact that $\Sigma_{A}$ contains the intensity information of the given image [15].

Wavelets have been used quite frequently as tools in many image processing applications such as feature extraction [16], compression [17], [18], face recognition [19], [20], image super resolution [2], [21], [22], and medical image enhancement [23]. The decomposition of images into different frequency ranges permits the isolation of the frequency components into certain subbands [24]. Stationary Wavelet Transformation (SWT) is very similar to DWT where there exists no scaling function. In other words the four output of SWT are as the same size as the original image [25]. The two-dimensional wavelet decomposition of an image is performed by applying the one-dimensional SWT along the rows of the image first, and then the results are decomposed along the columns. This operation leads into four decomposed subband images refer to Low-Low (LL), Low-High (LH), High-Low (HL), and HighHigh $(\mathrm{HH})$ whose size is the same size as the input image.

In this work, we have proposed a new method for medical image illumination enhancement and sharpening which is based on SWT. SWT is used to separate the input medical image into different frequency subbands, where LL subband is used in order to enhance the illumination and the high frequency subbands are used in order to enhance the edges of the image to obtain a sharper image. In this paper, the proposed method has been compared with conventional GHE, LHE technique and some state-of-art technique such as SVE and DWT+SVD. The results indicate the superiority of the proposed method over the aforementioned methods.

\section{The Proposed Medical Image Illumination EnHANCEMENT AND Sharpening Method}

As the most important contribution of the paper, an illumination enhancement and sharpening method is presented in this section, which, despite others proposed heretofore, makes use of SWT for decomposing the original image into the corresponding high- and low-frequency subbands. The general structure of the proposed technique is as follows. First, the image is equalized by means of GHE. Then SWT is applied to the equalized medical image, namely, A, which splits it into four subband images. As aforesaid, the edge information is embedded into the high-frequency subbands, whereas the LL subband contains, mainly, the illumination information. Thus separating the high frequency subbands from the lowfrequency ones, and employing them later on, at the final stage of the whole algorithm, will enhance the distinctiveness and sharpness of the edges.

At the next step, DWT is applied to both the input medical image and its LL subband. Subsequently, the matrices $\boldsymbol{U}$, $\sum$ and $\boldsymbol{V}$ are calculated through decomposing the foregoing items. Then a weighted average of the low-frequency subband image and the original image is obtained. The weights are calculated while making the following assumptions:

$$
\begin{array}{r}
\alpha_{1} \mu_{1}+\alpha_{2} \mu_{2}=128, \\
\alpha_{1}+\alpha_{2}=1,
\end{array}
$$

in which $\mu_{1}$ is the mean of the input medical image, and $\mu_{2}$ is that of the low frequency subband image. Besides, $\alpha_{1}$ and $\alpha_{2}$ represent the weight factors associated with them, respectively. Thus the above relationship can be reformulated as follows:

$$
\begin{aligned}
\alpha_{1} & =\frac{\mu_{2}-128}{\mu_{2}-\mu_{1}}, \\
\alpha_{1} & =\frac{128-\mu_{2}}{\mu_{2}-\mu_{1}} .
\end{aligned}
$$

The image output by the illumination enhancement module does possess considerably improved illumination, but it would usually suffer from the deficiency of being slightly smoothed, due to the nature of the averaging process. For overcoming the latter drawback, the image, at the next stage, is sharpened through reincorporating the high frequency subband into the resultant image. In other words, since the averaging module tends to reduce the sharpness of the edges, which are mainly denoted by the high-frequency subbands, the latter portion of 


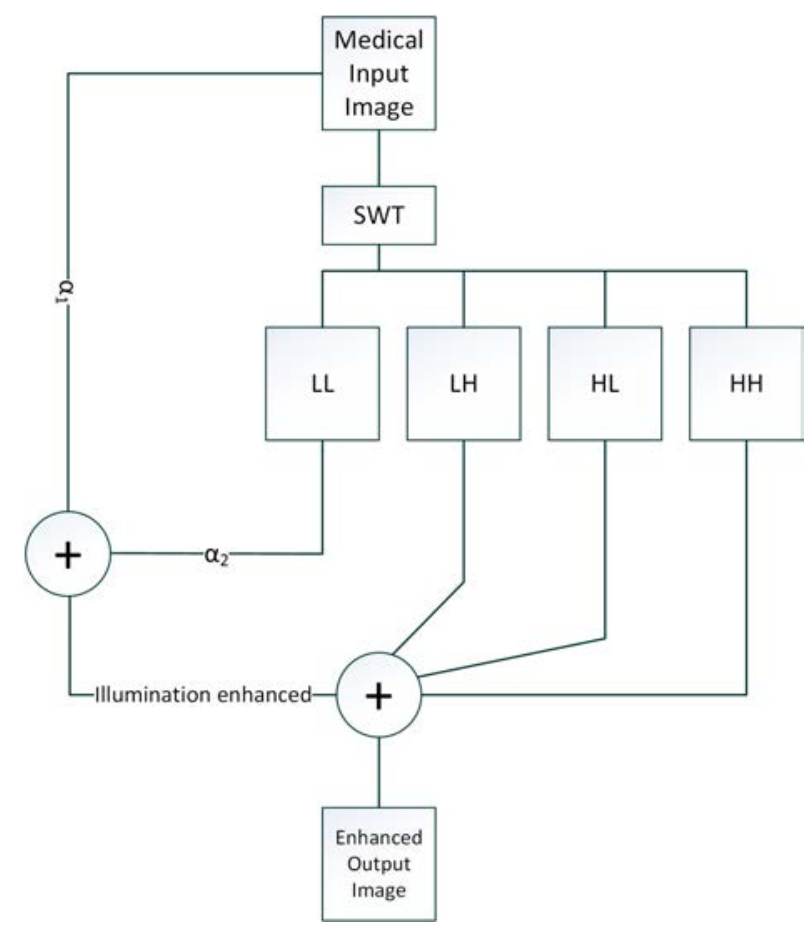

Şekil 2: A schematic diagram presenting the detailed steps of the proposed illumination and sharpening enhancement technique.

the image, while being represented in the frequency domain, is preserved before applying the illumination enhancement procedure. After performing the foregoing operation, the highfrequency subbands are recovered, in order to change the distinctiveness and sharpness level of the edges to the original state at which they would appear in the input medical image. To this end, Inverse SWT (ISWT) is applied to the illumination enhanced image, so as to transform the aforementioned average to the previous form, which is compatible with the highfrequency subband, and could be merged with it. On the other hand, the high-frequency subband image undergoes ISWT separately, being followed by constructing the final result through combining the latter two items.

Fig. 2 shows a schematic diagram illustrating all the steps of the proposed image enhancement technique. In the context of this paper, a db.9/7 wavelet function is utilized as the mother function of the SWT, where the experimental implementation results are presented in the next section, being succeeded by discussing its advantages while being compared against that of others having been suggested in the existing literature.

\section{EXPERIMENTAL RESULTS AND DISCUSSIONS}

As aforementioned, since the scale through which the nuances standing for certain medical conditions are presented is significantly small, and could play vital roles in timely detection and treatment of diseases, contrast and brightness are among the most important properties of medical images, which should be as high as possible, so that exploiting the information contained in them is guaranteed. For the sake of illustration of the effect of illumination on their quality and informative specifications, Fig. 3 and 4 show images of human brain taken

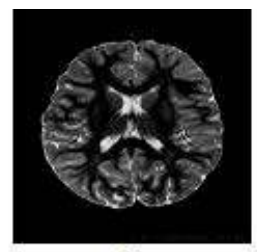

(a)

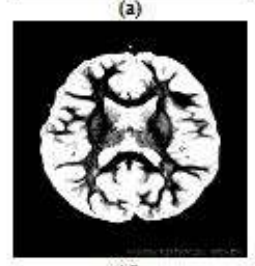

(d)

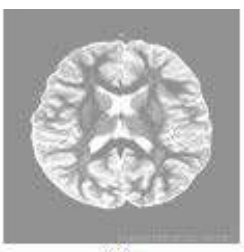

(b)

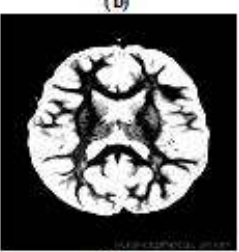

(e)

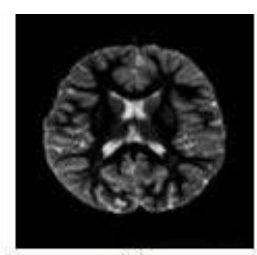

(c)

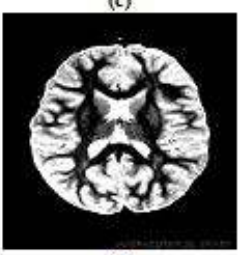

Şekil 3: Brain image (a) enhanced by image by using: GHE (b), LHE(c), SVE (d), SVE+DWT (e), and proposed SWT technique (f).

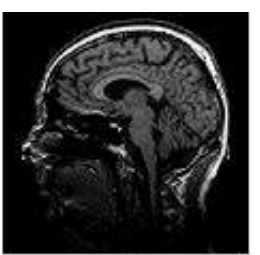

(a)

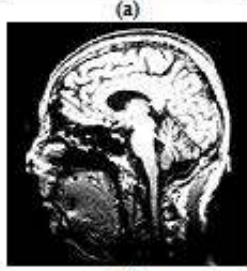

(d)

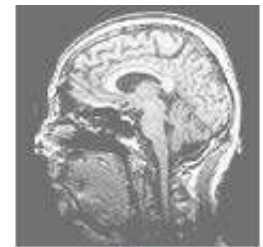

(b)

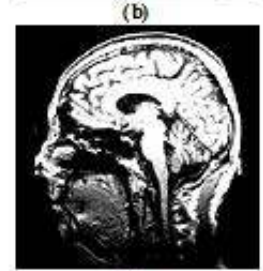

(e)

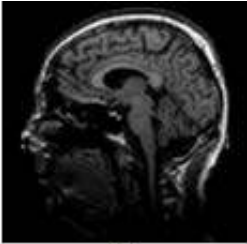

(c)

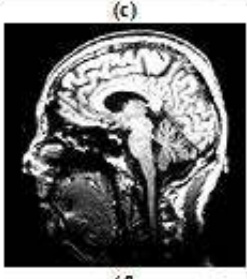

(f)
Şekil 4: Brain image (a) enhanced by image by using: GHE (b), LHE(c), SVE (d), SVE+DWT (e), and proposed SWT technique (f).

by an MRI scanner under different illumination circumstances. Each image has been equalized by means of different approaches, namely, GHE, LHE, SVE [8], DWT+SVE [2] and the sharpening and brightness enhancement method presented in this paper, whose results are shown in Figs. 3 and 4 (b) through (f).

Upon comparing the foregoing figures, one could conclude that the proposed method outperforms other classical and state-ofthe-art ones suggested in the literature, since it has led to both higher sharpness and enhanced brightness. Furthermore, in order to carry out the required objective, quantitative analyses, which would also be deemed a basis for statistically substantiating and generalizing the proposed method, it has been applied to 150 images that have been randomly chosen from a variety of databases. The outcomes of the latter verification procedure clearly demonstrate the superiority of the proposed techniques, which, as sought from the outset, corresponds to the conclusion made based on the qualitative evaluation. 


\section{CONCLUSION}

In this research paper, a new medical image illumination enhancement and sharpening technique based on SWT was proposed. The proposed technique decomposed the input image into four subbands by employing SWT. Afterwards the illumination of LL subband image was being enhanced by combining the input image and the LL subband image using weighted sum rule. Finally the output was obtained by applying ISWT on updated LL and the high frequency subbands of original image which was resulting in sharper image. The proposed technique was compared with the GHE, LHE, SVE, and DWT+SVD techniques and the visual result were illustrated in the paper. Qualitative ressults were confirming the superiority of the proposed technique over the conventional and the state-of-art techniques.

\section{ACKNOWLEDGEMENT}

This work is supported by Estonian Research Council Grant (PUT638).

\section{KAYNAKÇA}

[1] S.-C. Huang and W.-C. Chen, "A new hardware-efficient algorithm and reconfigurable architecture for image contrast enhancement," Image Processing, IEEE Transactions on, vol. 23, no. 10, pp. 4426-4437, 2014.

[2] H. Demirel, C. Ozcinar, and G. Anbarjafari, "Satellite image contrast enhancement using discrete wavelet transform and singular value decomposition," Geoscience and Remote Sensing Letters, IEEE, vol. 7, no. 2, pp. 333-337, 2010.

[3] G. Anbarjafari, S. Izadpanahi, C. Ozcinar, and H. Demirel, "Illumination compensation by using singular value decomposition and discrete wavelet transform," in Signal Processing and Communications Applications (SIU), 2011 IEEE 19th Conference on. IEEE, 2011, pp. 904-907.

[4] S. Li and B. Yang, "A new pan-sharpening method using a compressed sensing technique," Geoscience and Remote Sensing, IEEE Transactions on, vol. 49, no. 2, pp. 738-746, 2011.

[5] T. K. Kim, J. K. Paik, and B. S. Kang, "Contrast enhancement system using spatially adaptive histogram equalization with temporal filtering," Consumer Electronics, IEEE Transactions on, vol. 44, no. 1, pp. 82-87, 1998.

[6] G. Anbarjafari, C. Ozcinar, and H. Demirel, "Human vision inspired based image illumination enhancement by using local singular value decomposition and discrete wavelet transform," International Journal of Electronics Communication and Computer Engineering, vol. 6, no. 1, p. 14, 2015.

[7] S. Chitwong, T. Boonmee, and F. Cheevasuvit, "Enhancement of color image obtained from pca-fcm technique using local area histogram equalization," in International Symposium on Optical Science and Technology. International Society for Optics and Photonics, 2002, pp. 98-106.

[8] H. Demirel, G. Anbarjafari, and M. N. S. Jahromi, "Image equalization based on singular value decomposition," in Computer and Information Sciences, 2008. ISCIS'08. 23rd International Symposium on. IEEE, 2008, pp. 1-5.

[9] G. Anbarjafari, "An objective no-reference measure of illumination assessment," MEASUREMENT SCIENCE REVIEW, vol. 15, no. 6, 2015.

[10] H. Ibrahim and N. S. P. Kong, "Brightness preserving dynamic histogram equalization for image contrast enhancement," Consumer Electronics, IEEE Transactions on, vol. 53, no. 4, pp. 1752-1758, 2007.

[11] M. A. Rahman, S. Liu, S. Lin, C. Wong, G. Jiang, and N. Kwok, "Image contrast enhancement for brightness preservation based on dynamic stretching," International Journal of Image Processing (IJIP), vol. 9 , no. 4 , p. $241,2015$.
[12] G. Anbarjafari, "Face recognition using color local binary pattern from mutually independent color channels," EURASIP Journal on Image and Video Processing, vol. 2013, no. 1, pp. 1-11, 2013.

[13] T. Kim and H. S. Yang, "A multidimensional histogram equalization by fitting an isotropic gaussian mixture to a uniform distribution," in Image Processing, 2006 IEEE International Conference on. IEEE, 2006, pp. 2865-2868.

[14] A. R. Weeks, L. J. Sartor, and H. R. Myler, "Histogram specification of 24-bit color images in the color difference (cy) color space," Journal of electronic imaging, vol. 8, no. 3, pp. 290-300, 1999.

[15] Y. Tian, T. Tan, Y. Wang, and Y. Fang, "Do singular values contain adequate information for face recognition?" Pattern recognition, vol. 36, no. 3, pp. 649-655, 2003.

[16] W. He, Y. Zi, B. Chen, F. Wu, and Z. He, "Automatic fault feature extraction of mechanical anomaly on induction motor bearing using ensemble super-wavelet transform," Mechanical Systems and Signal Processing, vol. 54, pp. 457-480, 2015.

[17] A. M. Rufai, G. Anbarjafari, and H. Demirel, "Lossy image compression using singular value decomposition and wavelet difference reduction," Digital Signal Processing, vol. 24, pp. 117-123, 2014.

[18] A. Bolotnikova, P. Rasti, A. Traumann, I. Lusi, M. Daneshmand, F. Noroozi, K. Samuel, S. Sarkar, and G. Anbarjafari, "Block based image compression technique using rank reduction and wavelet difference reduction," in Seventh International Conference on Graphic and Image Processing. International Society for Optics and Photonics, 2015, pp. 981702-981702.

[19] H. Cho, R. Roberts, B. Jung, O. Choi, and S. Moon, "An efficient hybrid face recognition algorithm using pca and gabor wavelets," International Journal of Advanced Robotic Systems, vol. 11, no. 59, pp. 1-8, 2014.

[20] G. Anbarjafari and H. Demirel, Modern: Face Recognition. VDM Publishing, 2011.

[21] P. Rasti, H. Demirel, and G. Anbarjafari, "Image resolution enhancement by using interpolation followed by iterative back projection," in Signal Processing and Communications Applications Conference (SIU), 2013 21st. IEEE, 2013, pp. 1-4.

[22] H. Demirel and G. Anbarjafari, "Discrete wavelet transform-based satellite image resolution enhancement," Geoscience and Remote Sensing, IEEE Transactions on, vol. 49, no. 6, pp. 1997-2004, 2011.

[23] Y. Yang, Z. Su, and L. Sun, "Medical image enhancement algorithm based on wavelet transform," Electronics letters, vol. 46, no. 2, pp. 120-121, 2010.

[24] D. Li, X. Tang, and W. Pedrycz, "Face recognition using decimated redundant discrete wavelet transforms," Machine Vision and Applications, vol. 23, no. 2, pp. 391-401, 2012.

[25] S. Prasad, W. Li, J. E. Fowler, and L. M. Bruce, "Information fusion in the redundant-wavelet-transform domain for noise-robust hyperspectral classification," Geoscience and Remote Sensing, IEEE Transactions on, vol. 50, no. 9, pp. 3474-3486, 2012. 